\title{
Oral microbiota and mucositis in patients with head and neck cancer undergoing radiotherapy: literature review
}

\author{
Microbiota bucal e mucosite em pacientes com câncer de cabeça e pescoço \\ recebendo radioterapia: um estudo de revisão de literatura
}

\author{
Microbiota bucal y mucositis en pacientes con cáncer de cabeza y cuello que \\ recibe radioterapia: el artículo de revisión
}

\author{
Elerson GAETTI JARDIM JÚNIOR ${ }^{1}$ \\ Adriana de Sales CUNHA-CORREIA ${ }^{1}$ \\ Ana Cláudia OKAMOTO ${ }^{1}$ \\ Ellen Cristina GAETTI JARDIM ${ }^{2}$ \\ ${ }^{l}$ PhD. Department of Pathology and Clinical Propedeutics, São Paulo State University (Unesp), \\ School of Dentistry, Araçatuba-SP, Brazil \\ ${ }^{2}$ PhD. Department of Oral and Maxillofacial Surgery, School of Dentistry, Federal of Mato Grosso do Sul (UFMS), \\ Campo Grande-MS, Brazil
}

\begin{abstract}
The occurrence and severity of mucositis are the main complaints of patients with head and neck cancer submitted to radiotherapy (RT). This condition appears to be associated with changes in the oral microbiota and other side effects of RT, such as xerostomia and candidiasis. The aim of this study was to evaluate the effect of RT on the oral microbiota and its impact on radioinduced mucositis through literature review. Descriptors were selected for the collection of information in different databases, especially SciELO, BIREME, LILACS and PubMed. It was decided to consider only articles published since 1985. The descriptors radiotherapy, mucositis, dental caries, xerostomia, head and neck neoplasms and health promotion were used. It was selected 91 articles specifically discussing the microbiological aspects of mucositis, dental caries, oral candidiasis and microbial effects on the oral health of cancer patients, and 59 were included in the review. It was observed that microbial contamination is a secondary phenomenon capable of exacerbate the inflammation induced by the interaction of the radiation with the oral tissues, aggravating mucositis mainly in patients who present precarious conditions of oral hygiene, which reinforces the role of preventive dentistry in the follow up of the irradiated patient.

Descriptors: Radiotherapy; Mucositis; Dental Caries; Xerostomia; Head And Neck Neoplasms; Health Promotion.
\end{abstract}

\section{Resumo}

A ocorrência e a severidade da mucosite constituem as principais queixas dos pacientes com câncer de cabeça e pescoço submetidos à radioterapia (RT). Essa condição parece estar associada às modificações da microbiota bucal e aos demais efeitos colaterais da RT, como xerostomia e a candidíase. O presente trabalho de revisão da literatura teve como objetivo avaliar o efeito que a RT exerce sobre a microbiota bucal e seu impacto na mucosite radioinduzida através de revisão de literatura. Foram selecionados os descritores para a coleta de informações em diferentes bancos de dados, destacando-se SciELO, BIREME, LILACS e PubMed. Decidiu-se considerar apenas artigos publicados desde 1985. Utilizou-se como descritores os termos radioterapia, mucosite, cárie dentária, xerostomia, neoplasias de cabeça e pescoço e promoção da saúde. Foram selecionados 91 artigos que discutiam especificamente os aspectos microbiológicos da mucosite, cárie dentária, candidíase oral e efeitos microbianos na saúde bucal de pacientes oncológicos e 59 foram incluídos na revisão. Observou-se que a contaminação microbiana é fenômeno secundário capaz de agravar a inflamação induzida pela interação da radiação com os tecidos bucais, agravando-se, principalmente, em pacientes que apresentam condições precárias de higiene bucal, o que reforça o papel da odontologia preventiva no acompanhamento do paciente irradiado.

Descritores: Radioterapia; Mucosite; Cárie Dentária; Xerostomia; Neoplasias de Cabeça e Pescoço; Promoção da Saúde.

\begin{abstract}
Resumen
La ocurrencia y la gravedad de la mucositis son las principales quejas de los pacientes con cáncer de cabeza y cuello tratados con radioterapia (RT). Esta condición parece estar asociada con cambios en la microbiota bucal y los otros efectos secundarios de la RT como xerostomía y candidiasis. Este estudio bibliográfico fue evaluar el efecto que la RT tiene sobre la microbiota bucal y su impacto sobre la mucositis radio-inducida a través de revisión de la literatura. Se seleccionaron los descriptores para recoger dados de diferentes bases, destacando SciELO, BIREME, lilas y PubMed. Se decidió considerar sólo los artículos publicados desde 1985. Fue utilizado como descriptores radioterapia, mucositis, caries dental, xerostomía, neoplasias de cabeza y cuello y promoción de la salud. Se seleccionaron 91 artículos que analizan específicamente los aspectos microbiológicos de la mucositis, la caries dental, la candidiasis oral y efectos microbianos en la salud oral de los pacientes con cáncer; 59 fueron incluidos en la revisión. Se observó que la contaminación microbiana es fenómeno secundario pero puede agravar la inflamación inducida por la interacción de la radiación con los tejidos orales, empeorando, especialmente en pacientes con mala higiene oral, lo que refuerza el papel de la odontología preventiva en acompañamiento de los pacientes irradiados.

Descriptores: Radioterapia; Mucositis; Caries Dental; Xerostomía; Neoplasias de Cabeza y Cuello; Promoción de la Salud.
\end{abstract}

\section{INTRODUCTION}

In the treatment of head and neck cancer, the use of radiation therapy (RT) plays a central role, leading to a significant improvement in patients' survival, but at the expense of severe side effects, which can interfere with the compliance of patients, deterioration of quality of life, the progress and intensification of the therapeutic regimen ${ }^{1-4}$ Individuals undergoing RT, often report the occurrence of inflammation of mucosa (mucositis), xerostomia, dysphagia, dysgeusia and candidiasis, particularly in patients who have not received previous dental treatment before $\mathrm{RT}^{5-8}$.
The severity of these side effects, specially mucositis, depends on the dose/frequency of RT, volume and anatomical aspects of irradiated tissues, previous dental treatment, age, oral and general conditions of the patients, as well concomitant use of chemotherapy and surgical procedures ${ }^{5,9}$. These effects may be acute, occurring during the treatment or subsequent weeks, or chronic, detected months or years after $\mathrm{RT}^{10-11}$.

In general, mucositis generally is most frequent complaint $^{12}$. The impact of this condition on the patient's 
health is significant, and seems to be associated with candidiasis and severe xerostomia, affecting the vast majority of the irradiated subjects ${ }^{13,14}$, producing extreme discomfort and compromising acceptance, continuity and intensification of the treatment ${ }^{6,10,14}$. The tissue damage produced by RT on acinar cells of major salivary glands ${ }^{15}$ exacerbate the formation and retention of microbial biofilm, creating favorable conditions to secondary microbial colonization of ulcerated lesions on mucosa ${ }^{16}$.

Radio-induced mucositis is dose dependent, but the inflammatory process regresses after RT cessation. The severity of the mucositis diminishes more readily after RT than xerostomia ${ }^{17}$, which possibly exacerbates the patient's susceptibility to infectious conditions ${ }^{1,17}$, affecting the intensification or continuity of $\mathrm{RT}^{17}$. In this sense, the role of the oral microbiota in the development and exacerbation of mucositis still needs clarification, but this oral condition can be exacerbated by the concomitant presence of other local and/or systemic infectious processes ${ }^{16,18}$.

The development of xerostomia and mucositis is followed by several changes in oral microbiota, but the significance of such phenomenon remains unclear ${ }^{19}$. Some evidences suggest that oral environment might act as reservoirs of classical and opportunistic pathogens, facilitating the establishment of opportunistic infections, particularly in patients receiving chemotherapy and undergoing RT simultaneously ${ }^{19,20}$. In addition, it is evident the deterioration of dental health due to mucositis and radiation caries associated with the aggravation of xerostomia, amplifying the numbers of cariogenic cocci, reducing the $\mathrm{pH}$ of biofilm and cooperate, exacerbating the adhesion and proliferation of Candida on oral mucosa.

The presence of exogenous Gram-negative bacteria in the biofilm could affect the inflammatory conditions of the mucosa, allowing new pressures to the development of radiation induced mucositis ${ }^{20,21}$. Thus, the aim of this study was discuss the role played by microorganisms in the development and evolution of mucositis in patients with head and neck cancer undergoing RT.

\section{MATERIAL AND METHOD}

This study consists of a literature review and qualitative data analysis. Initially the descriptors for the collection of information in different databases were selected, highlighting the indexed SciELO (Scientific Electronic Library Online), BIREME (Virtual Health Library), LILACS (Latin American and Caribbean Health Sciences), MEDLINE (International Literature on Health Sciences), PubMed (National Library of Medicine) databases. It was decided to consider only articles published since 1985 to prevent further difficulties with the taxonomy of most common genera and oral microbial species, particularly those associated with the etiopathogenesis of orofacial infections.

The following descriptors for research were used: radiotherapy, mucositis, dental caries, xerostomia, head and neck cancer, and health promotion. Out of these publications, studies that do not properly describe the oral conditions of the patients involved, characteristics of RT and/or oncologic treatment, as well theses, dissertations, books and informational texts that were not published in scientific journals were excluded. A total of 399 publications were selected and 91 discussed specifically the microbiological aspects of the mucositis, dental caries, oral candidiasis and microbial effects on oral health of oncologic patients. The 59 most relevant were included in the review.

\section{ORAL MICROBIOTA OF THE PATIENT WITH HEAD AND NECK CANCER}

The oral microbiota of patients with head and neck cancer presented several peculiarities, such as a higher frequency of colonization of yeasts of the genus Candida ${ }^{22,23}$, which have been implicated in the production of nitrosamines capable to activate proto-oncogenes responsible for the development of the head and neck cancer $^{24}$, besides Gram-positive anaerobes of the genus Actinomyces, Gram-negative anaerobes of genera Fusobacterium, Prevotella, and Porphyromonas, microaerophillics such as Capnocytophaga, and Gramnegative enteric rods of the family Enterobacteriaceae ${ }^{25}$.

The high prevalence of the species of Enterobacteriaceae on the surface of malignant neoplasms in the mouth may have impact on oral and/or systemic infectious diseases and could reflect the microbial adhesion abilities of bacteria and receptors of the neoplastic cells ${ }^{23}$. In addition, the presence of enteric Gram-negative rods on the surface of oral soft tissues could exacerbate microbial proteolytic activity on fibronectin and expose receptors for adhesion of other members of the family Enterobacteriaceae. In addition, the Gram-negative microorganisms are still able to affect, even secondarily, the oral conditions of the irradiated patients, almost always exacerbating inflammatory processes ${ }^{18}$, which follow the direct damage produced by the $\mathrm{RT}^{15}$, particularly during the development of secondary local or systemic infections ${ }^{26}$. Gram-negative anaerobes, such as the genera Fusobacterium, Porphyromonas and Prevotella, induce the release of different pro-inflammatory cytokines and, thereby, exacerbate the radio-induced mucositis ${ }^{27}$.

\section{RADIATION CARIES, ORAL STREPTOCOCCI AND MUCOSITIS}

The result of pronounced and sometimes persistent xerostomia is the change of oral microbiota, producing a significant increase of oral acidogenic cocci in supragingival biofilm, and a significant elevation in salivary levels of cariogenic cocci, particularly Streptococcus mutans ${ }^{28-30}$. This phenomenon is cumulative, usually established after 2000 cGy of radiation, accompanying the severity and persistence of xerostomia ${ }^{17}$. However, the use of sodium fluoride in aqueous solutions or gel minimizes the changes of cariogenic cocci populations, constituting a recognized strategy to prevent the rampant caries associated with RT and xerostomia ${ }^{30-32}$. Then, the elevations of cariogenic microorganisms in RT might be understood as result of the absence or precariousness of the preventive measures and the poor hygiene conditions of the patients and their deterioration along $\mathrm{RT}^{33,34}$.

In radiotherapy centers where preventive dentistry is considered relevant and plays a central role in the prevention of side effects of RT, populations of cariogenic cocci are under partial control ${ }^{19,30}$, consisting transient phenomenon ${ }^{33,35,36}$, and hygiene standards evidences relevant improvement during RT and follow-up period, particularly when intensity modulated radiation therapy is used, which produces less pronounced effects on the salivary glands ${ }^{19,37}$

Oral streptococci such as Streptococcus anginosus, $S$. mitis, S. mutans, S. oralis, S. sanguinis, and S. sobrinus present mucolytic capacity by the production of glycosidases and may exacerbate chemotherapy and radiotherapy induced mucositis ${ }^{38,39}$. According to Vanhoecke et al. ${ }^{16}$, it is possible to observe significant changes in the composition and 
thickness of the oral muco, which, together with a possible increase in the virulence of these microorganisms in immunocompromised patients ${ }^{40}$ could contribute to the deterioration of the conditions of the mucosa.

\section{RADIO-INDUCED MUCOSITIS CANDIDIASIS}

AND

Mucositis is associated with ulcerated areas, hinder nutrition and might facilitate the deployment of local or systemic infections ${ }^{5}$, usually caused by opportunistic microorganisms, such as enteric pathogens, anaerobic Gramnegative rods and yeasts ${ }^{7,19,20,41,42}$ sometimes already present in higher proportions in cancer patients before $\mathrm{RT}^{23}$.

The presence, severity and persistence of xerostomia seem to be the main factors associated with the presence of candidiasis in irradiated patients, facilitating the colonization of surfaces that previously did not harbor these fungi, allowing the growth of yeast populations ${ }^{43,44}$. This phenomenon is also exacerbated by the acidification of the oral biofilm and the reduction of the buffer capacity of the residual saliva. The prevalence and populations of yeasts are directly related to $\mathrm{RT}^{23,34,44}$, being involved in the severity of mucositis and secondary infections.

Patients presenting the highest populations of these yeasts prior to RT are also the first to develop clinically detectable infection ${ }^{7,20}$, which reinforces the need for antifungal preventive approach for oral candidiasis in irradiated patients ${ }^{20,21}$. On the other hand, as opportunistic pathogens, the high prevalence and populations of fungi also reflect the poor conditions of oral hygiene and deterioration along the $\mathrm{RT}^{34}$, as well nutritional deficiencies and loss of weight in irradiated patients. Oral candidiasis in RT patients might also be associated to the exacerbation of virulence of the fungi ${ }^{40}$.

The occurrence of Candida sp. varies from 20 to $70 \%$ in patients undergoing RT, and some studies suggest that other species besides $C$. albicans are more favored in the irradiated patients ${ }^{7,45}$. However, literature has failed to discover any advantage for non-albicans Candida during or after $\mathrm{RT}^{23,34,44,46,47}$.

The prevention/control of oral candidiasis, by improving oral hygiene standards, use of antifungal solutions and nutritional support, could also be a measure with impact on mucositis intensity in irradiated patients ${ }^{7,34}$ particularly the systemic use of fluconazole and aqueous solution of nystatin ${ }^{20,21,34,47}$.

\section{MUCOSITIS, ORAL BACTERIAL MICROBIOTA, ENTEROBACTERIACEAE AND BIOFILM}

The occurrence and populations of autochthonous microorganisms of the oral microbiota may be higher among patients with head and neck squamous cell carcinoma ${ }^{23}$, but this phenomenon is not universal ${ }^{12,19,20,48}$. Alcohol and tobacco consumption and poor hygiene might facilitate oral colonization of the patients by exotic microbial species $^{12,20,48}$. Patients with severe xerostomia are generally colonized by some Gram-negative microaerophilic and anaerobic bacteria. Thus, new strategies of RT that reduce tissue damage on salivary glands tend to minimize the impact on oral microbiota and produce a reduction of the prevalence and populations of autochthonous microorganisms ${ }^{19,49}$.

After the emergence of ulcerations and lesions near the gingival sulcus in irradiated patients with mucositis, creating a more irregular surface and exposing new receptors for microbial adhesion, new possibilities for microbial colonization opens, allowing adhesion high populations of the pathogens present in the biofilm of oncologic patients with oropharyngeal carcinoma ${ }^{25}$. Most of these pathogens are Gram-negative and with a wide spectrum of virulence, exacerbating the production and release of cytokines and chemokines ${ }^{16}$.

Among Gram-negative bacteria, enteric rods of the family Enterobacteriaceae have been implicated in severe mucositis $^{20,21,50}$ and the oral carriage of these microorganisms is resilient to antimicrobials commonly used, what needs combined strategies involving improvement of oral hygiene to reduce the presence of enteric rods in the mouth of mucositis patients, particularly in patients presenting severe xerostomia ${ }^{32,51}$. Their presence on the surface of the oral soft tissues could exacerbate the microbial proteolytic activity on the fibronectin and connective tissues, intensifying the mucositis by the induction of inflammation by direct action of LPS and release of interleukins Il-1 and Il- $6^{23}$.

The occurrence and populations of the main periodontopathogens are not usually affected by RT, but this aspect is deeply dependent on oral hygiene of the patients ${ }^{49}$. RT has been associated with the reduction of the blood supply to the irradiated areas, leading to a significant reduction of local immunity, redox potential of the tissues and delay of the wound repair, creating favorable conditions for the proliferation obligate anaerobes, such as genera Fusobacterium, Prevotella, Porphyromonas, and Treponema ${ }^{23}$, most of them considered putative periodontopathogens. In addition, radiation-induced xerostomia appears to affect the populations of anaerobic bacteria in oral cavity and exacerbate the prevalence and proportions of non-oral opportunistic pathogens, particularly staphylococci, enteric rods and cocci, as well pseudomonads in the oral biofilm from irradiated patients with adequate oral hygiene conditions ${ }^{19,32,51,52}$. However, only Gramnegative anaerobes producing black pigment (Porphyromonas spp. and Prevotella spp.) have been implicated in RT subgingival microbiota ${ }^{23}$.

These anaerobes frequently associated with periodontitis present a metabolism based on the fermentation of amino acids, end up upregulating the release of cytokines and pro-inflammatory chemokines ${ }^{16,18}$, which could exacerbate the initial acute effects of mucositis.

The effects of RT are relevant and have a deep impact on the quality of life of irradiated patients, mainly due to mucositis, radiation caries, xerostomia, dysphagia and dysgeusia $^{1,17}$. Thus, preventive dental care should be used to minimize these conditions and must be implemented before, during and after $\mathrm{RT}^{8,19,21,51}$. The importance of preventive dental care and oral hygiene are aspects that constitute a common place ${ }^{13,17,19,53,54}$, but many radiotherapy centers in Brazil do not offer this support, which remains without adequate follow-up.

Moreover, since most of patients undergoing RT in Brazil for cancer treatment present low socioeconomic conditions and inadequate oral hygiene standards ${ }^{20,48,55}$, the relevance of protocols capable to restore the equilibrium between patients' immune response and microbial biofilm should be considered priority in the prevention of side effects of RT. Moreover, ameliorate xerostomia by using sialogogues and artificial saliva is considered relevant to reduce the impact of RT on oral ecology and, as consequence on severity of mucositis. However, literature emphasize the needs of dental and periodontal examinations, as well as the elimination local infections by mean of 
restorative dentistry, endodontic and periodontal treatments and surgery ${ }^{7,9,20}$. The use of chemical control of biofilm must be considered for patients with poor oral hygiene and for those ones evidencing significant deterioration of oral health ${ }^{56}$. Surgical procedures should be avoided during or soon after end of oncologic treatment due to vascular and immunological changes induced RT, particularly when associated with chemotherapy, preventing osteoradionecrosis.

Some studies have proposed the selective elimination of the enteric rods in the oral microbiota in irradiated patients with mucosites ${ }^{57,58}$, but the benefits of such approach are uncertai ${ }^{59}$. In general, microbial suppression in biofilm is transient and must be followed by improvement of oral hygiene.

\section{CONCLUSION}

Mucositis is primarily the result of direct damage of oral tissues by RT, but microorganisms are capable to exacerbate inflammation by mean of enzymatic destruction of mucosa and up-regulation of the production and release of pro-inflammatory cytokines. The most commonly found species belong to genus Candida, family Enterobacteriaceae and black-pigmented oral anaerobes.

\section{REFERENCES}

1. Vissink A, Jansma J, Spijkervet FKL, Burlage FR, Coppes RP. Oral sequelae of head and neck radiotherapy. Crit Rev Oral Biol Med. 2003; 14(3):199212.

2. Alhilali L, Reynolds AR, Fakhran S. Osteoradionecrosis after radiation therapy for head and neck cancer: differentiation from recurrent disease with $\mathrm{CT}$ and PET/CT imaging. Am J Neuroradiol. 2014; 35(7):1405-11.

3. Silva MFA, Melo AVG, Barbosa KGN, Pereira JV, Alves PM, Gomes DQC. Evaluation of oral health status and quality of life of head and neck cancer patients after radiation therapy. Serb Dent J. 2014; 61(1):14-20.

4. Kaul R, Angrish P, Arora K, Jain P. Dental complications of head and neck radiotherapy and their management: A review. Univ Res J Dent. 2015; 5(3):165-70.

5. Bensadoun RJ, Magné N, Marcy PY, Demard F. Chemotherapy- and radiotherapy-induced mucositis in head and neck cancer patients: new trends in pathophysiology, prevention and treatment. Eur Arch Otorhinolaryngol. 2001; 258(9):481-7.

6. Duncan GG, Epstein JB, Tu D, El Sayed S, Bezjak A, Ottaway $\mathrm{J}$, et al. Quality of life, mucositis, and xerostomia from radiotherapy for head and neck cancers: a report from the ncic ctg hn2 randomized trial of an antimicrobial lozenge to prevent mucositis. Head Neck 2005; 27(5):421-8.

7. Jham BC,França EC, Oliveira RR, Santos VR, Kowalski LP, da Silva Freire AR. Candida oral colonization and infection in Brazilian patients undergoing head and neck radiotherapy: a pilot study. Oral Surg Oral Med Oral Pathol Oral Radiol Endod. 2007; 103(3):355-8.

8. Behl M, Manchanda AS, Sachdeva HS, Kaur T, Sarang S. Radiotherapy in oral cavity: consequences and current management regimes. J Adv Med Dent Scie Res 2014; 2(4):127-35.

9. Minhas S, Kashif M, Altaf W, Nagi AH. Oral candidiasis: complication of concomitant chemoradiotherapy in patients with oral squamous cell carcinoma. BMRJ. 2016; 11(1):1-11.
10. Spetch L. Oral complications in the head and neck irradiated patient. Introduction and scope of the problem. Support Care Cancer. 2002; 10(1):36-9.

11. Campos MIC, Campos CN, Aarestrup FM, Aarestrup BJ V. Oral mucositis in cancer treatment: natural history, prevention and treatment. Mol Clin Oncol 2014; 2(3):337-40.

12. De Freitas EM, Nobre SA, Pires MB, Faria RV, Batista AU, Bonan PR. Oral Candida species in head and neck cancer patients treated by radiotherapy. Auris Nasus Larynx 2013; 40(4):400-4.

13. Veness MJ, Foroudi F, Gebski V, Timms I, Sathiyaseelan Y, Cakir B, et al. Use of topical misoprostol to reduce radiation-induced mucositis: Results of a randomized, double-blind, placebocontrolled trial. Australas Radiol. 2006; 50(5):468-74.

14. Peterson DE, Srivastava R, Lalla RV. Oral mucosal injury in oncology patients: perspectives on maturation of a field. Oral Dis. 2015; 21(2):133-41.

15. Scarantino C, LeVeque F, Swann RS, White R, Schulsinger A, Hodson DI, et al. Effect of pilocarpine during radiation therapy: results of RTOG 97-09, a phase III randomized study in head and neck cancer patients. J Support Oncol. 2006; 4(5):252-8.

16. Vanhoecke B, De Ryck T, Stringer A, Van de Wiele T, Keefe D. Microbiota and their role in the pathogenesis of oral mucositis. Oral Dis 2015; 21(1):17-30.

17. Sun HB, Gao XJ, Deng J, Li NL, Lu HJ. Progress of oral sequelae during head-neck radiotherapy. Chin J Dent Res. 2010; 13(1):51-5.

18. Meurman JH. Oral microbiota and cancer. J Oral Microbiol. 2010 Aug 10;2. doi: 10.3402/jom.v2i0.5195.

19. Schuurhuis JM, Stokman MA, Witjes MJ, Langendijk JA, van Winkelhoff AJ, Vissink A, et al. Head and neck intensity modulated radiation therapy leads to an increase of opportunistic oral pathogens. Oral Oncol. 2016; 58:32-40.

20. Gaetti-Jardim EJ, Ciesielski FI, de Sousa FR, Nwaokorie F, Schweitzer CM, Avila-Campos MJ. Occurrence of yeasts, pseudomonads and enteric bacteria in the oral cavity of patients undergoing head and neck radiotherapy. Braz J Microbiol. 2011; 42(3):1047-55.

21. Leung WK, Jin LJ, Yam WC, Samaranayake LP. Oral colonization of aerobic and facultative anaerobic Gramnegative rods and cocci in irradiated, dentale, xeostomic individuals. Oral Microbiol Immunol. 2001; 16(1):1-9.

22. Schelenz S, Abdallah S, Gray G, Stubbings H, Gow I, Baker P, et al. Epidemiology of oral yeast colonization and infection in patients with hematological malignancies, head neck and solid tumors. J Oral Pathol Med. 2011; 40(1):83-9.

23. Sonalika WG, Amsarvadani Tayaar S, Bhat KG, Patil BR, Muddapur MV. Oral microbial carriage in oral squamous cell carcinoma patients at the time of diagnosis and during radiotherapy. A comparative study. Oral Oncol. 2012; 48(9):881-6.

24. Krogh P. The role of yeasts in oral cancer by means of endogenous nitrosation. Acta Odontol Scand. 1990; 48(1):85-8.

25. Nagy KN, Sonkodi I, Szöke I, Nagy E, Newman HN. The microflora associated with human oral carcinomas. Oral Oncol. 1998; 34(4):304-8.

26. Gaetti-Jardim Júnior E, Fardin AC, Gaetti-Jardim EC, de Castro AL, Schweitzer CM, Avila-Campos MJ. Microbiota associated with chronic osteomyelitis of the jaws. Braz J Microbiol. 2010; 41(4):1056-64 
27. Martinho FC, Leite FR, Nóbrega LMM Endo MS, Nascimento GG, Darveau RP, et al. Comparison of Fusobacterium nucleatum and Porphyromonas gingivalis lipopolysaccharides clinically isolated from root canal infection in the induction of pro-inflammatory cytokines secretion. Braz Dent J. 2016; 27(2):202-7.

28. Keene HJ, Fleming TJ. Prevalence of caries-associated microflora after radiotherapy in patients with cancer of the head and neck. Oral Surg Oral Med Oral Pathol. 1987; 64(4):421-6.

29. Meng L, Liu J, Peng B, Fan M, Nie M, Chen Z. et al. The persistence of $\mathrm{S}$. mutans in nasopharyngeal carcinoma patients after radiotherapy. Caries Res. 2005; 39(6):484-9.

30. Meca LB, Souza FRN, Tanimoto HM, Castro AL, Gaetti-Jardim Júnior E. Influence of preventive treatment on mutans streptococci counts in patients undergoing head and neck radiotherapy. J Appl Oral Sci. 2009; 17 Suppl:5-12.

31. Shiboski CH, Hodgson TA, Ship JA, Schiodt M. Management of salivary hypofunction during and after radiotherapy. Oral Surg Oral Med Oral Pathol Oral Radiol Endod. 2007;103 Suppl:S66.e1-19.

32. Almståhl A, Wikström M, Fagerberg-Mohlin, B. Microflora in oral ecosystems in subjects with radiationinduced hyposalivation. Oral Dis. 2008; 14(6):541-9.

33. Epstein JB, Chin EA, Jacobson JJ, Rishiraj B, Le N. The relationships among fluoride, cariogenic oral flora, and salivary flow rate during radiation therapy. Oral Surg Oral Med Oral Pathol Oral Radiol Endod. 1998; 86(3):286-92.

34. Yogitha PVV, Lakshmi N, Lakshmi KR, Krishna PBM, Cheemala SS. Isolation and speciation of genus Candida in patients undergoing chemotherapy and radiotherapy for head and neck tumours. Int J Res Med Sci. 2015 May; 3(5):1189-94.

35. Almståhl A, Wikström M. Oral microflora in subjects with reduced salivary secretion. J Dent Res. 1999; 78(8):1410-6.

36. Eliasson L, Carlén A, Almståhl A, Wikström M, Lingström P. Dental plaque $\mathrm{pH}$ and micro-organisms during hyposalivation. J Dent Res. 2006; 85(4):334-8.

37. Gao L, Hu Y, Wang Y, Jiang W, He Z, Zhu C, et al. Exploring the variation of oral microbiota in supragingival plaque during and after head-and-neck radiotherapy using pyrosequencing. Arch Oral Biol. 2015; 60(9):1222-30.

38. Tong HC, Gao XJ, Dong XZ. Non-mutans streptococci in patients receiving radiotherapy in the head and neck area. Caries Res. 2003; 37(4):261-6.

39. Olczak-Kowalczyk D, Daszkiewicz M, KrasuskaSlawińska, Dembowska-Bagińska B, Gozdowski $\mathrm{D}$, Daszkiewicz P, et al. Bacteria and Candida yeasts in inflammations of the oral mucosa in children with secondary immunodeficiency. J Oral Pathol Med. 2012; 41(7):568-76.

40. Ueta E, Tanida T, Yoneda K, Yamamoto T, Osaki T. Increase of Candida cell virulence by anticancer drugs and irradiation. Oral Microbiol Immunol. 2001; 16(4):243-9.

41. Redding SW, Dahiya MC, Kirkpatrick WR, Coco BJ, Patterson TF, Fothergill AW, et al. Candida glabrata is an emerging cause of oropharyneal candidiasis in patients receiving radiation for head and neck cancer,
Oral Surg Oral Med Oral Pathol Oral Radiol Endod. 2004; 97(1):47-52.

42. Real CV, Sayáns MP, Suárez-Peñaranda JM, Sanchez FP, Vila PG, Carrión AB, et al. Role of microbiota and inflammation in osteonecrosis of the jaw. Int J Clin Exp Pathol. 2016; 9(4):4188-96.

43. Grötz KA, Genitsariotis S, Vehling D, Al-Nawas B. Long-term oral Candida colonization, mucositis and salivary function after head and neck radiotherapy. Support Care Cancer. 2003; 11(11):717-21.

44. Suryawanshi H, Ganvir SM, Hazarey VK, Wanjare VS. Oropharyngeal candidosis relative frequency in radiotherapy patient for head and neck cancer. J Oral Maxillofac Pathol. 2012; 16(1):31-7.

45. Bakki SR, Kantheti LP, Kuruba KK, Poosarla C, Reddy $\mathrm{R}$, Baddam VR, et al. Candidal carriage, isolation and species variation in patients undergoing radiotherapy and chemotherapy for head and neck tumours. J Dr NTR Univ Health Sci. 2014; 3(1):28-34.

46. Ramirez-Amador V, Silverman S Jr, Mayer P, Tyler M, Quivey J. Candidal colonization and oral candidiasis in patients undergoing oral and pharyngeal radiation therapy. Oral Surg Oral Med Oral Pathol Oral Radiol Endod. 1997; 84(2):149-53.

47. Belazi M, Velegraki A, Koussidou-Eremondi T, Andreadis D, Hini S, Arsenis G, Eliopoulou C, et al. Oral Candida isolates in patients undergoing radiotherapy for head and neck cancer: prevalence, azole susceptibility profiles and response to antifungal treatment. Oral Microbiol Immunol. 2004; 19(6):347-51.

48. Bonan PR, Lopes MA, Pires FR, Almeida OP. Dental management of low socioeconomic level patients before radiotherapy of the head and neck with special emphasis on the prevention of osteoradionecrosis. Braz Dent $\mathrm{J}$ 2006; 17(4):336-42.

49. Al-Nawas B, Grötz KA. Prospective study of the long term change of the oral flora after radiation therapy. Support Care Cancer. 2006;14(3):291-6.

50. Napeñas JJ, Brennan MT, Bahrani-Mougeot FK, Fox PC, Lockhart PB. Relationship between mucositis and changes in oral microflora during cancer chemotherapy. Oral Surg Oral Med Oral Pathol Oral Radiol Endod 2007; 103(1):48-59.

51. Almståhl A, Wikström M, Fagerberg-Mohlin B. Microflora in oral ecosystems and salivary secretion rates. A 3-year follow-up after radiation therapy to the head and neck region. Arch Oral Biol. 2015; 60(9):118795.

52. Abu Shara KA, Ghareeb MA, Zaher S, Mobacher A, Khalifa MC, Saleh SZ. Radiotherapeutic effect on oropharyngeal flora in patients with head and neck cancer. J Laryngol Otol. 1993;107(3):222-7.

53. Barasch A, Coke JM. Cancer therapeutics: an update on its effects on oral health. Periodontol 2000. 2007; 44:4454.

54. Weinberg MA, Segelnick SL, Kye W. Dental complications of head and neck cancer radiotherapy. US Pharm. 2011; 36(9)(Oncology suppl):3-7.

55. Rosales ACMN, Esteves SCB, Jorge J, Almeida OP, Lopes MA. Dental needs in Brazilian patients subjected to head and neck radiotherapy. Braz Dent J. 2009; 20(1):74-7.

56. Donnelly JB, Bellm LA, Epstein JB, Sonis ST, Symonds RP. Antimicrobial therapy to prevent or treat oral mucositis. Lancet Infect Dis. 2003; 3(7):405-12. 
57. Spijkervet FK, Van Saene HK, Van Saene JJ, Panders AK Vermey A, Mehta DM, et al. Effect of selective elimination of the oral flora on mucositis in irradiated head and neck cancer patients. J Surg Oncol. 1991; 46(3):167-73

58. Spijkervet FKL, Van Saene HK, Van Saene JJ, Panders AK Vermey A, Mehta DM. Mucositis prevention by selective elimination of oral flora in irradiated head and neck cancer patients. J Oral Pathol Med 1990; 19(10):486-9.

59. Wijers OB, Levendag PC, Harms ER, Gan-Teng AM, Schmitz PI, Hendriks WD, et al. Mucositis reduction by selective elimination of oral flora in irradiated cancers of the head and neck: a placebocontrolled double-blind randomized study. Int $\mathrm{J}$ Radiat Oncol Biol Phys. 2001;50(2):343-52.

\section{CONFLICTS OF INTERESTS}

The authors declare no conflicts of interests.

\section{CORRESPONDING AUTHOR}

Ellen Cristina Gaetti Jardim

ellengaetti@gmail.com

Received 24/11/2016 Accepted 01/01/2017 